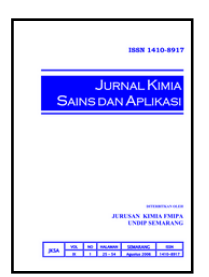

\title{
Uji Aktivitas Trichoderma Viride dalam Hidrolisis Selulosa Eceng Gondok (Eichhornia Crassipes) dengan Variasi Temperatur dan Waktu Inkubasi
}

\author{
Wirnia Sinar Setyani ${ }^{\mathrm{a}}$, Purbowatiningrum Ria Sarjono ${ }^{\mathrm{a}}$, Nies Suci Mulyani ${ }^{\mathrm{a}^{*}}$ \\ a Biochemistry Laboratory, Chemistry Department, Faculty of Sciences and Mathematics, Diponegoro University, Jalan Prof. \\ Soedarto, Tembalang, Semarang 50275 \\ * Corresponding author: niessuci@live.undip.ac.id
}

\begin{tabular}{l} 
Article Info \\
\hline Keywords: \\
Trichoderma viride, \\
cellulose hydrolysis, \\
optimum \\
temperature and \\
incubation time
\end{tabular}

\begin{abstract}
Trichoderma viride activity was tested in hydrolyzing cellulose water hyacinth (Eichhornia crassipes) with variation of temperature and incubation time to obtain optimum temperature and incubation time. Trichoderma viride activity was based on the ability of the cellulase enzyme produced to break the $\beta-1,4-$ glycoside bond on the cellulose chain in water hyacinth and was observed based on the amount of glucose produced as a result of the hydrolysis reaction. The results of the Trichoderma viride activity test showed that the highest glucose levels were obtained at $35^{\circ} \mathrm{C}$ and the optimum incubation time of glucose at 96 hours was $1.3864 \mathrm{mg} / \mathrm{L}$.
\end{abstract}

\begin{abstract}
Abstrak
\end{abstract}
Kata kunci: Trichoderma viride, hidrolisis selulosa, temperatur dan waktu inkubasi optimum

\section{Pendahuluan}

Selulosa adalah karbohidrat paling melimpah dan sering ditemukan di alam [1]. Selulosa terdiri atas monomer glukosa yang dihubungkan dengan ikatan $\beta-$ 1,4-glikosida. Dengan menghidrolisis ikatan glikosida dapat diperoleh glukosa yang kemudian diharapkan dapat digunakan untuk berbagai tujuan, seperti produksi sirup gula, asam organik [2] dan bioetanol [3].

Salah satu sumber selulosa yang mudah ditemukan adalah eceng gondok. Tumbuhan ini memiliki kecepatan tumbuh yang tinggi [4] sehingga dianggap sebagai gulma yang dapat merusak lingkungan perairan [5]. Eceng gondok dapat bermanfaat dalam bidang bioteknologi sebagai alternatif substrat lignoselulosa [4] dan media pertumbuhan mikroorganisme. Eceng gondok mengandung bobot kering selulosa 21,50\%, hemiselulosa 33,90\% dan lignin 7,01\% [4].

Proses hidrolisis selulosa dapat dilakukan dengan bantuan mikroorganisme selulolitik salah satunya adalah Trichoderma viride. Menurut [6], Trichoderma viride merupakan kapang yang berpotensi memproduksi selulase dalam jumlah yang relatif banyak yang mampu mendegradasi ikatan $\beta-1,4$-glikosida pada selulosa untuk menghasilkan glukosa. Berdasarkan penelitian terdahulu yang dilakukan [3], Trichoderma viride mampu mendegradasi selulosa pada batang pisang dan 
menghasilkan glukosa dengan jumlah yang cukup tinggi sebesar $0,5676 \mathrm{mg} / \mathrm{mL}$.

Dalam melakukan aktivitasnya, Trichoderma viride sebagai penghasil enzim selulase dipengaruhi oleh temperatur dan waktu inkubasi. Temperatur mempengaruhi pertumbuhan, jumlah sel dan daya tahan hidup mikroba, aktivitas metabolisme sel dan sistem reaksi enzim yang bekerja di dalam sel. Waktu inkubasi yang merupakan waktu yang diperlukan oleh Trichoderma viride untuk menghasilkan enzim selulase dan membentuk produk hidrolisis, oleh karena itu diperlukan temperatur dan waktu inkubasi optimum bagi Trichoderma viride yang aktivitasnya ditandai dari produk glukosa yang dihasilkan. Untuk mengetahui temperatur dan waktu inkubasi optimum aktivitas Trichoderma viride pada eceng gondok maka dilakukan uji aktivitas dengan rentang temperatur 30 sampai $60^{\circ} \mathrm{C}$ dan waktu inkubasi 24 sampai 96 jam.

Pada penelitian ini dimaksudkan untuk memanfaatkan eceng gondok sebagai sumber karbon untuk pertumbuhan Trichoderma viride dan melakukan uji aktivitas Trichoderma viride dalam menghidrolisis eceng gondok untuk menghasilkan glukosa dengan variasi temperatur dan waktu inkubasi sehingga diperoleh data aktivitas berbagai temperatur dan waktu inkubasi dalam menghasilkan glukosa.

Penentuan aktivitas Trichoderma viride didasarkan pada kemampuannya dalam menghidrolisis selulosa pada eceng gondok, setelah proses delignifikasi, menjadi glukosa. Kadar glukosa ditentukan dengan metode Nelson-somogyi.

\section{Metodologi}

\section{Alat dan Bahan}

Bahan yang digunakan adalah biakan murni kapang Trichoderma viride TNCC6013, eceng gondok, aquades, media PDB (Potato Dextrose Broth), CMC (Carboxymethyl cellulose), reagen Nelson Somogyi, buffer asetat 0,05M $\mathrm{pH}$ 5, reagen arsenomolibdat, $\mathrm{Ba}(\mathrm{OH})_{2} 0,01 \mathrm{M}, \mathrm{ZnSO}_{4}$ $0,01 \mathrm{M}$ dan $\mathrm{NaOH}$.

Alat yang digunakan dalam penelitian ini antara lain: alat-alat gelas laboratorium kimia, lampu spirtus, autoklaf, penangas air, inkubator, mikropipet, alumunium foil, spektrofotometer UV-Vis, kuvet, sentrifus, neraca analitik, shaker, oven, kompor listrik, kertas label, pH stick, korek api, kertas saring, tabung reaksi, rak tabung reaksi, blender, pendingin, kapas, kain kasa, botol semprot dan pipet tetes. Alat-alat dari kaca dibungkus menggunakan alumunium foil dan plastik lalu diautoklaf pada temperatur $121^{\circ} \mathrm{C}$ tekanan 2 atm selama 20 menit, termasuk dalam hal ini media cair CMC (Carboxymethyl cellulose), PDB (Potato Dextrose Broth) dan eceng gondok.

\section{Delignifikasi Eceng Gondok}

Eceng gondok yang sudah dikeringkan dilarutkan dengan larutan $\mathrm{NaOH}(\% \mathrm{w} / \mathrm{v})$, kemudian dipanaskan pada temperatur $90^{\circ} \mathrm{C}$ selama 3 jam (Hamisan dkk.,2009). Larutan disaring dengan kertas saring, selanjutnya residu larutan yang merupakan eceng gondok bebas lignin dicuci dengan aquades hingga $\mathrm{pH}$ residu netral. Eceng gondok dikeringkan di dalam oven dan diblender hingga berbentuk serbuk. Serbuk tersebut yang digunakan untuk uji lanjutan.

\section{Peremajaan dan Pengadaptasian Trichoderma viride} ke Media Modifikasi

Inokulum kapang Trichoderma viride dari biakan induk ditempatkan secara aseptik pada $50 \mathrm{~mL}$ media PDB yang telah disterilkan dan dishaker pada temperatur ruang selama 192 jam sampai kapang tumbuh. Kemudian inokulum kapang Trichoderma viride yang sudah tumbuh tersebut ditempatkan secara aseptik dan bertahap pada $50 \mathrm{~mL}$ media PDB modifikasi (antara CMC dengan kentang dan dekstrosa) yang telah disterilkan dan kemudian dishaker pada temperatur ruang selama 192 jam sampai kapang tersebut tumbuh.

Tabel 1. Modifikasi Media PDB dengan CMC

\begin{tabular}{ccc}
\hline Adaptasi Media & PDB (\%) & CMC (\%) \\
\hline PDB & 100 & 0 \\
PDB I & 75 & 25 \\
PDB II & 50 & 50 \\
PDB III & 25 & 75 \\
PDB IV & 0 & 100 \\
\hline
\end{tabular}

Inolulom kapang yang tumbuh pada media PDB IV kemudian ditempatkan secara aseptik dan bertahap pada $50 \mathrm{~mL}$ media substrat eceng gondok (CMC diganti dengan eceng gondok) yang telah disterilkan dan dishaker pada temperatur ruang selama 192 jam sampai kapang tumbuh.

Tabel 2. Modifikasi Media CMC dengan Eceng Gondok

\begin{tabular}{ccc}
\hline Adaptasi Media & CMC (\%) & Eceng Gondok (\%) \\
\hline CMC & 100 & 0 \\
CMC I & 50 & 50 \\
CMC II & 0 & 100 \\
\hline
\end{tabular}

\section{Pembuatan Kurva Pertumbuhan}

Sebanyak 28 buah erlenmeyer masing-masing diisi dengan $50 \mathrm{~mL}$ media eceng gondok dalam buffer asetat pH 5 kemudian disterilisasi dengan autoklaf selama 20 menit. Pada 12 buah erlenmeyer masing-masing ditambahkan $1 \mathrm{~mL}$ inokulum kapang Trichoderma viride (sebagai sampel) secara aseptik dan 12 buah erlenmeyer yang lain dijadikan sebagai kontrol. Kemudian ke-24 erlenmeyer tersebut dishaker pada temperatur ruang, selanjutnya sampel diambil tiap 24 jam sekali selama kurun waktu 288 jam untuk diukur berat keringnya. Penentuan pertumbuhan kapang Trichoderma viride dilakukan menggunakan metode pengukuran berat kering. Data yang didapatkan adalah jumlah berat kering yang diplotkan terhadap waktu sehingga akan diperoleh grafik jumlah berat kering vs waktu.

\section{Pembuatan Stater}

Inokulum kapang Trichoderma viride diambil dan ditempatkan secara aseptik pada $25 \mathrm{~mL}$ media cair yang 
telah disterilkan untuk pembuatan stater. Kemudian Erlenmeyer tersebut dishaker pada temperatur ruang selama kurun waktu tertentu (berdasarkan kurva pertumbuhan).

Fermentasi Kapang Trichoderma viride pada Media Eceng Gondok dengan Variasi Temperatur dan Waktu Inkubasi

Untuk menentukan pengaruh variasi temperatur pada aktivitas hidrolisis selulosa pada eceng gondok oleh kapang Trichoderma viride, diperlukan 7 buah erlenmeyer $250 \mathrm{~mL}$ yang berisi $50 \mathrm{~mL}$ media eceng gondok dalam buffer asetat $\mathrm{pH} 5$ yang sudah disterilkan. Diambil sebanyak $1 \mathrm{~mL}$ inokulum (dari stater) dan ditempatkan secara aseptik ke dalam masing-masing erlenmeyer tersebut. Kemudian semua erlenmeyer diinkubasi selama waktu tertentu (fase log dari kurva pertumbuhan). Untuk mengetahui temperatur optimum serta pengaruh temperatur terhadap aktivitas Trichoderma viride dalam menghidrolisis eceng gondok, maka erlenmeyer yang berisi inokulum diinkubasi pada temperatur yang bervariasi yaitu $30^{\circ} \mathrm{C}, 35^{\circ} \mathrm{C}, 40^{\circ} \mathrm{C}, 45^{\circ} \mathrm{C}$, $50^{\circ} \mathrm{C}, 55^{\circ} \mathrm{C}, 60^{\circ} \mathrm{C}$ dan masing-masing dengan waktu inkubasi 24 sampai 96 jam, setelah itu dilakukan pengukuran kadar glukosa.

Penentuan Aktivitas Trichoderma viride dalam Menghidrolisis Eceng Gondok Menghasilkan Glukosa dengan Metode Nelson-Somogyi.

Erlenmeyer yang berisi inokulum diinkubasi pada temperatur yang bervariasi selama waktu tertentu, filtrat (media cair) diukur kandungan glukosanya (hasil hidrolisis eceng gondok oleh kapang Trichoderma viride). Selanjutnya disiapkan 7 buah tabung reaksi yang masing-masing diisi dengan 0,1 $\mathrm{mL}$ larutan inkubasi (media cair kapang) dari masing-masing hasil inkubasi dari perlakuan 2.7. Kemudian larutan inkubasi diencerkan dengan aquades sampai volumenya menjadi 1,5 $\mathrm{mL}$ serta masing-masing tabung diisi dengan $0,2 \mathrm{~mL}$ $\mathrm{Ba}(\mathrm{OH})_{2} 0,01 \mathrm{M}$ dan $0,2 \mathrm{~mL} \mathrm{ZnSO}_{4}$ 0,01M. Selanjutnya disentrifus selama 30 menit. Larutan hasil sentrifus diambil sebanyak $1 \mathrm{~mL}$ ditempatkan pada tabung reaksi kemudian ditambahkan dengan $1 \mathrm{~mL}$ larutan Nelson Somogyi, agar larutan dapat cepat bereaksi maka tabung reaksi yang berisi larutan dipanaskan di dalam air mendidih selama 15 menit, lalu didinginkan. Setelah itu dibubuhi $1 \mathrm{~mL}$ reagen arsenomolibdat dan dibiarkan selama 1 menit. Larutan hasil yang berwarna hijau kebiruan diencerkan dengan aquades hingga volume menjadi $10 \mathrm{ml}$. Kemudian masing-masing tabung reaksi dilakukan pengukuran absorbansi pada panjang gelombang maksimum (754 nm) dengan Spektrofotometer UV-Vis. Kadar glukosa dapat ditentukan dari nilai absorbansi yang diperoleh dengan menggunakan kurva standar.

\section{Hasil dan Pembahasan}

Delignifikasi Eceng Gondok

Di alam selulosa selalu berikatan dengan lignin dan hemiselulosa membentuk suatu lignoselulosa. Keberadaan lignin akan menghambat proses hidrolisis selulosa karena lignin merupakan molekul kompleks yang terdiri atas unit-unit fenilpropana yang umumnya sulit didegradasi [7].

Serbuk eceng gondok dilarutkan dengan larutan $\mathrm{NaOH}$ agar lignin dapat larut dan selulosa dapat mengendap. Selulosa mengendap pada kondisi alkali sehingga dengan penambahan $\mathrm{NaOH}$, selulosa akan mengendap [8]. Lignin dalam larutan $\mathrm{NaOH}$ akan membentuk garam fenolat yang larut dalam air. Garam fenolat terbentuk maka ikatan antara selulosa dengan lignin akan lepas sehingga diperoleh selulosa dalam keadaan bebas lignin.

\section{Peremajaan dan Pengadaptasian Trichoderma viride}

Peremajaan Trichoderma viride dilakukan agar Trichoderma viride aktif saat digunakan dan maksimal perannya. Pengadaptasian Trichoderma viride pada media pertumbuhan dilakukan secara bertahap. Media awal dari biakan murni Trichoderma viride adalah PDA sehingga adaptasi diawali dari media PDA ke media PDB, kemudian dilanjutkan ke media PDB modifikasi CMC untuk tahap adaptasi awal Trichoderma viride pada sumber karbonnya, yaitu kentang dan dektrosa ke CMC. Adaptasi Trichoderma viride ke media PDB modifikasi CMC ditunjukkan pada tabel 3.

Tabel 3. Pertumbuhan Trichoderma viride pada Media PDB Modifikasi CMC

\begin{tabular}{ccc}
\hline PDB (\%) & CMC (\%) & Hasil Pengamatan \\
\hline 100 & 0 & Tumbuh \\
75 & 25 & Tumbuh \\
50 & 50 & Tumbuh \\
25 & 75 & Tumbuh \\
2 & 98 & Tumbuh \\
\hline
\end{tabular}

Dari tabel 3 dapat diketahui bahwa pada berbagai variasi persentase sumber karbon dari media PDB modifikasi CMC, Trichoderma viride mampu tumbuh dengan baik. Trichoderma viride hanya mampu tumbuh sampai CMC 98\% dan PDB 2\% karena kapang ini masih membutuhkan nutrien dari media PDB.

Tahap adaptasi selanjutnya adalah media PDB modifikasi CMC ke media eceng gondok untuk adaptasi selanjutnya dari Trichoderma viride pada sumber karbonnya, yaitu CMC ke eceng gondok. Pengadaptasian ke media eceng gondok juga dilakukan secara bertahap agar memudahkan Trichoderma viride dalam beradaptasi. Hasil pengadaptasian ditunjukkan pada tabel 4.

Tabel 4. Pertumbuhan Trichoderma viride pada Media Modifikasi Eceng Gondok

\begin{tabular}{ccc}
\hline CMC $(\%)$ & Eceng Gondok $(\%)$ & Hasil Pengamatan \\
\hline 98 & 0 & Tumbuh \\
50 & 50 & Tumbuh \\
0 & 100 & Tumbuh \\
\hline
\end{tabular}

Dari tabel 4 dapat diketahui bahwa pada media modifikasi eceng gondok, Trichoderma viride mampu tumbuh dengan baik, dengan kandungan eceng gondok $100 \%$. 


\section{Pembuatan Kurva Pertumbuhan}

Pembuatan kurva pertumbuhan dilakukan dengan metode berat kering yaitu dengan menghitung pertambahan massa sel dari Trichoderma viride selama 288 jam. Trichoderma viride dalam media cair diambil setiap 24 jam untuk kemudian disaring dan dikeringkan lalu ditimbang massanya.

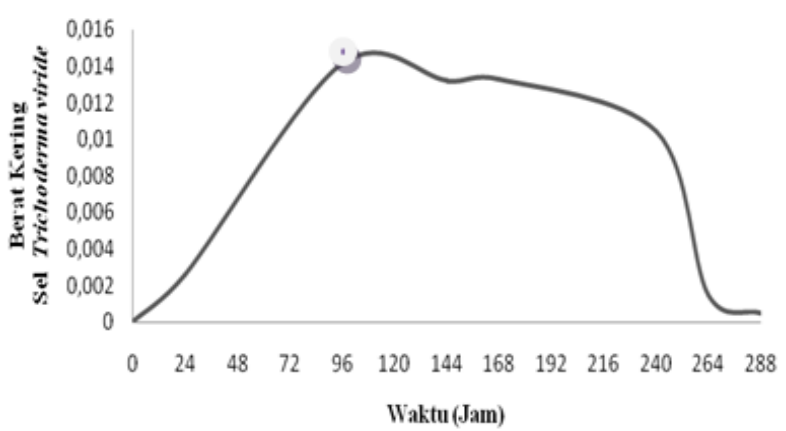

Gambar 1. Grafik Kurva Pertumbuhan Trichoderma viride

Dari gambar 1 dapat diketahui bahwa waktu yang tepat untuk panen sel Trichoderma viride agar dapat digunakan untuk proses fermentasi selanjutnya yaitu pada jam ke-96 yang berada pada fase eksponensial. Pada fase ini pertumbuhan sel Trichoderma viride yang paling maksimal sehingga pada fase ini juga akan dihasilkan enzim selulase yang maksimal

Uji Aktivitas Trichoderma viride dalam Hidrolisis Eceng Gondok dengan Variasi Temperatur dan Waktu Inkubasi

Pada inkubasi jam ke-24, diperoleh kadar glukosa dengan kisaran 0,6-1,1 mg/L. Aktivitas Trichoderma viride menghidrolisis selulosa dan menghasilkan glukosa pada jam ke-24 dapat dilihat pada gambar 2 .

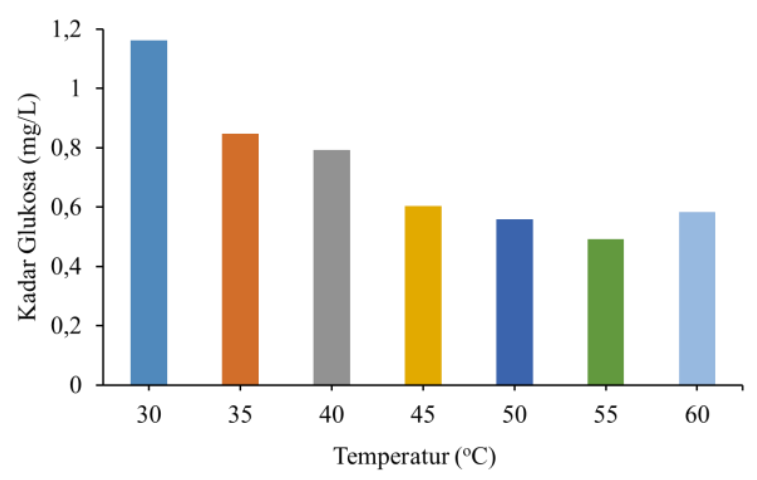

Gambar 2. Grafik Kadar Glukosa pada berbagai Variasi Temperatur pada Jam ke-24

Pada gambar 2 menunjukkan bahwa Trichoderma viride melakukan aktivitasnya pada semua temperatur dan menghasilkan glukosa sebagai produk hidrolisis. Pada temperatur $30,35,40$ dan $45^{\circ} \mathrm{C}$ terukur kadar glukosa yang lebih tinggi dibandingkan pada temperatur 50, 55 dan $60^{\circ} \mathrm{C}$ karena pada temperatur yang lebih tinggi, kemampuan Trichoderma viride dalam menghasilkan enzim untuk menghidrolisis selulosa menjadi berkurang.
Pada jam ke-48, temperatur $30,35,40,45$ dan $60^{\circ} \mathrm{C}$ mengalami penurunan kadar glukosa sedangkan pada temperatur $50^{\circ} \mathrm{C}$ dan $55^{\circ} \mathrm{C}$ sedikit mengalami peningkatan kadar glukosa dari awal inkubasi yang terlihat pada gambar 3 .

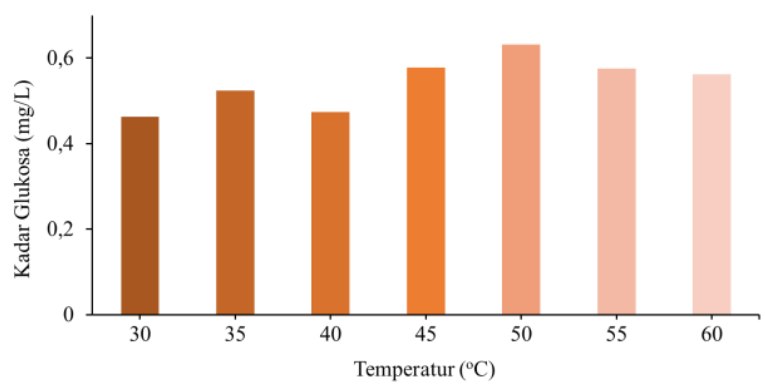

Gambar 3. Grafik Kadar Glukosa pada Berbagai Variasi Temperatur pada Jam ke-48

Hal ini menunjukkan bahwa penurunan pada temperatur $30,35,40,45$ dan $60^{\circ} \mathrm{C}$ ini disebabkan kapang Trichoderma viride menggunakan glukosa yang berasal dari hasil hidrolisis pada jam ke-24 sebagai sumber karbon. Menurut [9]Martina dkk. (2002), mikroorganisme akan menggunakan sumber karbon yang lebih sederhana terlebih dahulu seperti glukosa sebelum menggunakan selulosa.

Pada hari ketiga atau jam ke-72 terjadi peningkatan kadar glukosa pada tiap temperatur. Pada temperatur $35^{\circ} \mathrm{C}$ dihasilkan kadar glukosa paling tinggi dibandingkan temperatur $30,40,45,50,55$ dan $60^{\circ} \mathrm{C}$ yang ditunjukkan pada gambar 4 berikut ini.

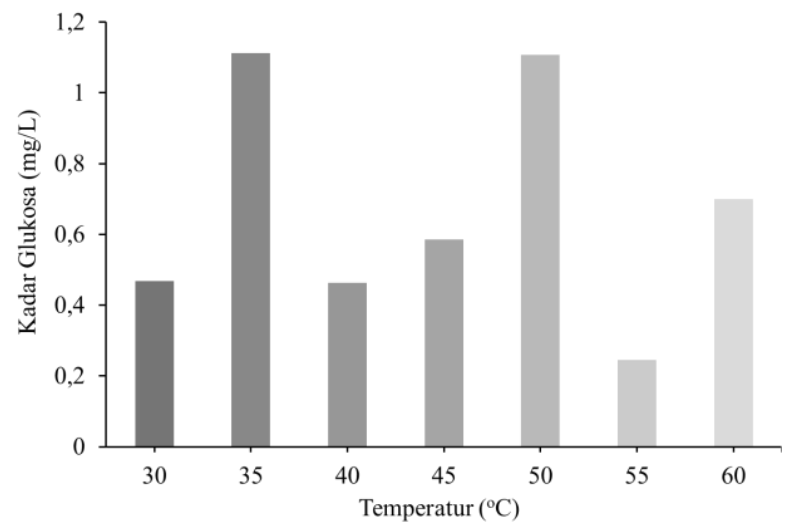

Gambar 4. Grafik Kadar Glukosa pada Berbagai Variasi Temperatur pada Jam ke-72

Pada inkubasi 72 jam ini, temperatur $35^{\circ} \mathrm{C}$ menunjukkan bahw Trichoderma viride memberikan aktivitas yang tinggi dengan dihasilkan glukosa yang tinggi yaitu sebesar 1,1118 mg/L.

Pada inkubasi jam ke-96 dengan data kadar glukosa pada gambar 5 menunjukkan bahwa terjadi peningkatan kadar glukosa pada temperatur 30,35 dan $40^{\circ} \mathrm{C}$. Pada temperatur $35^{\circ} \mathrm{C}$, dihasilkan kadar glukosa yang paling tinggi dibandingkan temperatur lainnya yaitu sebesar $1,3864 \mathrm{mg} / \mathrm{L}$. 


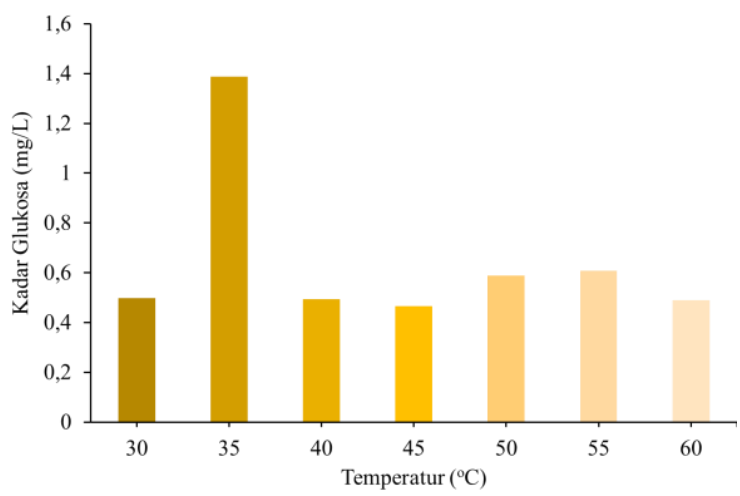

Gambar 5. Grafik Kadar Glukosa pada Berbagai Variasi Temperatur pada Jam ke-96

Pada temperatur $35^{\circ} \mathrm{C}$ telah menunjukkan kadar glukosa yang tinggi dari waktu inkubasi jam ke-72 hingga jam ke-96 sehingga temperatur ini merupakan temperatur optimum untuk kapang Trichoderma viride dalam mensintesis kompleks enzim selulase yang mampu menghidrolisis selulosa dan menghasilkan glukosa yang tinggi.

Berdasarkan pengamatan yang ditunjukkan dari gambar 2 hingga 5 dapat disimpulkan bahwa temperatur optimum hidrolisis selulosa terdapat pada temperatur $35^{\circ} \mathrm{C}$ yang memiliki kadar glukosa tertinggi pada inkubasi jam ke-96 yaitu sebesar 1,3864 mg/L.

\section{Kesimpulan}

Berdasarkan hasil penelitian dan pembahasan yang telah dipaparkan sebelumnya, maka dapat disimpulkan bahwa pada penelitian ini diperoleh Trichoderma viride yang mampu tumbuh pada media pertumbuhan eceng gondok dan aktivitas tertinggi Trichoderma viride dalam hidrolisis selulosa dari eceng gondok pada temperatur optimum $35^{\circ} \mathrm{C}$ dan waktu inkubasi optimum dalam menghasilkan glukosa pada jam ke-96 sebesar 1,3864 $\mathrm{mg} / \mathrm{L}$ dari 0,25 gram bubuk eceng gondok.

\section{Daftar Pustaka}

[1] G. Ramanathan, S. Banupriya, D. Abirami, Production and optimization of cellulase from Fusarium oxysporum by submerged fermentation, CSIR, 2010.

[2] Xue-Cai Hao, Xiao-Bin Yu, Zhong-Li Yan, Optimization of the medium for the production of cellulase by the mutant Trichoderma reesei WX-112 using response surface methodology, Food Technology and Biotechnology, 44, 1, (2006) 89-94

[3] D.S. Kamara, Rachman, S.D., dan Gaffar, S., , Degradasi Enzimatik Selulosa dari Batang Pohon Pisang untuk Produksi Enzim Selulase dari Kapang Trichoderma viride, Fakultas Matematika dan Ilmu Pengetahuan Alam, Universitas Padjajaran, Bandung, (2006)

[4] SK Deshpande, MG Bhotmange, T Chakrabarti, PN Shastri, Production of cellulase and xylanase by Trichoderma reesei (QM 9414 mutant), Aspergillus niger and mixed culture by solid state fermentation (SSF) of water hyacinth (Eichhornia crassipes), (2008)
[5] Enny K Artati, Ahmad Effendi, Tulus Haryanto, Pengaruh Konsentrasi Larutan Pemasak Pada Proses Delignifikasi Eceng Gondok dengan Proses Organosolv, Ekuilibrium, 8, 1, (2009) 25-28

[6] Mary Mandels, James Weber, The production of cellulases, in, ACS Publications, 1969.

[7] Mohammad J Taherzadeh, Keikhosro Karimi, Enzymatic-based hydrolysis processes for ethanol from lignocellulosic materials: A review, BioResources, 2, 4, (2007) 707-738

[8] Nur Richana, Tun Tedja Irawadi, M Anwar Nur, Illah Sailah, Khaswar Syamsu, Yandra Arkenan, Ekstraksi xilan dari tongkol jagung, J. Pascapanen, 4, 1, (2007) $38-43$

[9] A Martina, Nuryati Yuli, Mumu Sutisna, Optimasi beberapa faktor fisik terhadap laju degradasi selulosa kayu albasia (Paraserianthes falcataria L. Nielsen) dan karboksimetilselulosa (CMC) secara enzimatik oleh jamur, Jurnal Natur Indonesia, 4, 2, (2002) 156-163 